\title{
Nanofiltration of sweet whey by spiral wound organic membranes: Impact of hydrodynamics
}

\author{
Romain JEANTET ${ }^{\mathrm{a}}$, Jesus RodRÍGUEZ ${ }^{\mathrm{b}}$, Anita GAREM ${ }^{\mathrm{b} *}$ \\ ${ }^{\text {a }}$ Laboratoire de technologie alimentaire, ENSAR, 65 rue de Saint-Brieuc, \\ 35042 Rennes Cedex, France \\ b Laboratoire de recherches de technologie laitière, INRA, 65 rue de Saint-Brieuc, \\ 35042 Rennes Cedex, France
}

\begin{abstract}
The influence of permeation flux $J$ and wall shear stress $\tau_{w}$, on performances of the nanofiltration of concentrated sweet whey at volume reduction ratio $2,18{ }^{\circ} \mathrm{C}$ and using organic membranes was studied. It was concluded that sweet whey nanofiltration could be optimised through the parameter $J / \tau_{w}$, since $J$ and $\tau_{w}$ act together in a competing mechanism of convection/erosion at the membrane surface, that governs membrane fouling and selectivity. Hence, the overall fouling was strongly dependent on the ratio $J / \tau_{w}$, with a critical $J / \tau_{w}$ value of approximately 6.0 . When $J / \tau_{w}<6.0$, the total membrane fouling was relatively low and almost independent on operating conditions. For higher ratios of $J / \tau_{w}$, there was a spectacular increase in fouling and a very strong dependence between the fouling index and $J / \tau_{w}$. Simultaneously, selectivity was altered under these conditions, with higher retention of monovalent ions and lower retention of lactose. Finally, optimal hydrodynamic conditions were defined in the range 3-6. Under these conditions, longer operating times, lower chemical oxygen demand in permeate and higher demineralization could be expected at lower processing costs.
\end{abstract}

nanofiltration / hydrodynamic / sweet whey / fouling

\section{INTRODUCTION}

Nowadays, NF (membrane nominal molecular weight cut-off ranging between 0.2 and 1 ) is widely used in the dairy industry for the concentration and selective dem- ineralization of acid and sweet whey. There would be about $150000-200000 \mathrm{~m}^{2}$ of NF membranes installed for the dairy industry all over the world, either by substituting NF for RO membranes or as totally new equipment. NF membranes which are suitable for

\footnotetext{
* Correspondence and reprints. agarem@labtechno.roazhon.inra.fr.
} 
dairy applications generally exhibit a high permeability for monovalent ions (between $40-90 \%$ ), and a low or very low permeability for multivalent ions (between 5-20\%) and organic compounds (proteins, lactose, urea) $[12,17]$. However, NF membrane operation is not always efficient, and there are frequently problems with selectivity (losses of lactose in the permeate), and with productivity (fouling, reduction of the duration of functioning) [4].

In most practical applications with pressure-driven processes, fouling of the membrane occurs during the process, and this represents one of the major operating problems resulting in the reduction of selectivity and productivity of the process. The general consensus is that a surface layer (also called dynamic membrane) is formed on the membrane surface during the operation, and once this surface layer is formed, it regulates the permeability and the selectivity of the membrane, regardless of its intrinsic properties [13]. In crossflow filtration of whey using organic membranes, the most important fouling components are the whey proteins, which adsorb to the membrane and inside the pores [16]. Whey minerals such as calcium and phosphate cause severe fouling, especially in the case of acid whey, due to the presence of higher contents of insoluble salts (i.e. colloidal calcium phosphate) $[5,16]$. Lactose, small nitrogenous components, like peptides, urea, amino acids, and whey lipids, have only a minor contribution to fouling.

Some studies have demonstrated that the hydrodynamic operating conditions of membrane crossflow processes are the most important parameters responsible for its adequate performance. In this way, at a constant VRR, the permeation flux $(J)$ governs mass transport by convection towards the membrane, whereas the wall shear stress $\left(\tau_{w}\right)$ governs the transport by erosion, hydrodynamic diffusion of solutes from the membrane towards the feed fluid. Therefore, performance of the process (selectivity and productivity) greatly depends on these parameters: $J, \tau_{w}$ and VRR and hence, at a constant VRR, on the ratio $J / \tau_{w}$, which is characteristic of the membrane, the fluid, and independent of the characteristics of the installation.

Considering that only few studies have been related to the role of $J / \tau_{w}$ on NF membrane performance, our purpose was to determine an optimum $J / \tau_{w}$ for the best NF separation features of sweet whey using spiral wound organic membranes. In order to simulate the behaviour of one stage of an industrial multistage NF plant, each experiment was carried out at constant volume reduction ratio (VRR), temperature, $J$ and $\tau_{w}$.

\section{MATERIAL AND METHODS}

\subsection{Nanofiltration}

\subsubsection{Experimental equipment}

The NF unit was an U01-Lab installation (Filtration Engineering, New Hope, Minnesota, USA) equipped with a Desal 5 (DK 3840 C, Osmonics, Minnetonka, Minnesota, USA) spiral wound NF membrane, with a total area of $7.9 \mathrm{~m}^{2}$ and a molecular weight cut-off of $200 \mathrm{~g} \cdot \mathrm{mol}^{-1}$ [10].

\subsubsection{Cleaning procedure}

Cleaning of the installation and the membrane was performed before and after NF experiments as described by Jeantet [9]. The cleaning procedure was repeated until the resistance of the clean membrane $\left(R_{m}\right)$ was recovered $( \pm 5 \%)$.

\subsubsection{Whey concentration}

Emmental cheese whey obtained from a local dairy plant (Préval, Montauban, France) was concentrated to a VRR 2 at $45 \pm 1{ }^{\circ} \mathrm{C}$, flow velocity $1.1 \mathrm{~m} \cdot \mathrm{s}^{-1}$, and TP between $25-30 \times 10^{5} \mathrm{~Pa}$. The concentrated 
whey was then cooled to $2-4{ }^{\circ} \mathrm{C}$ and sodium azide $\left(0.2 \mathrm{~g} \cdot \mathrm{kg}^{-1}\right)$ was added in order to prevent microbial growth.

The composition $\left(\mathrm{g} \cdot \mathrm{kg}^{-1}\right)$ of the concentrated whey (VRR 2) used in the experimental study is shown in Table I. The $\mathrm{pH}$ of all whey samples immediately after concentration was $6.2 \pm 0.2$, and did not change to any appreciable extent during the different NF experiments.

\subsubsection{Nanofiltration experiments}

Experiments were performed at $18 \pm 1{ }^{\circ} \mathrm{C}$ and VRR constant (VRR 2) by recycling both the permeate and the retentate into the feed tank until a filtered volume (FV) of $20 \mathrm{~L} \cdot \mathrm{m}^{-2}$. Twenty-five experiments were performed for $J / \tau_{w}$ ratios within the range 1.0 and 9.3 , corresponding to $J$ and $\tau_{w}$ lying between $10-30 \mathrm{~L} \cdot \mathrm{h}^{-1} \cdot \mathrm{m}^{-2}$ and $3.1-11.6 \mathrm{~Pa}$, respectively.

The wall shear stress $\left(\tau_{w}, \mathrm{~Pa}\right)$ was calculated as follows:

$$
\tau_{w}=\frac{\Delta \mathrm{P} \cdot \mathrm{d}}{4 \cdot 1}
$$

where, $\Delta \mathrm{P}=$ pressure drop across the membrane $(\mathrm{Pa})$ ranging between $0.15 \times 10^{5}$ and $0.65 \times 10^{5} \mathrm{~Pa}$ during the experiments; $\mathrm{l}=$ length of the module $(\mathrm{m})$, and $\mathrm{d}=$ hydraulic diameter of the membrane $(\mathrm{m})$, calculated according to van Gauwbergen and Baeyens [19].

\subsubsection{Assessment of fouling}

The hydraulic resistances of the clean membrane $\left(R_{m}\right)$, the overall fouling $\left(R_{f}\right)$, the irreversible fouling $\left(\mathrm{R}_{\mathrm{if}}\right)$ and the reversible fouling $\left(R_{r f}\right)$ were calculated according to Daufin et al. [3].

\subsection{Physicochemical analyses}

The $\mathrm{pH}$ of samples was determined at $20{ }^{\circ} \mathrm{C}$ on a Radiometer $\mathrm{pH}$-meter. Total solids content was determined according to
Table I. Composition $\left(\mathrm{g} \cdot \mathrm{kg}^{-1}\right)$ and mineral content $\left(\mathrm{g} \cdot \mathrm{kg}^{-1}\right)$ of the concentrated sweet whey (VRR 2) used for nanofiltration experiments.

\begin{tabular}{lr}
\hline $\mathrm{pH}$ & $6.2 \pm 0.2$ \\
& $127.2 \pm 2.7$ \\
Total solids & $17.1 \pm 0.4$ \\
Protein & $3.4 \pm 0.1$ \\
$\mathrm{NPN}$ & $8.1 \pm 0.1$ \\
Ash & $102.2 \pm 1.9$ \\
Lactose & \\
$\mathrm{Ca}^{2+}$ & $0.67 \pm 0.04$ \\
$\mathrm{Mg}^{2+}$ & $0.15 \pm 0.01$ \\
$\mathrm{Na}^{+}$ & $0.62 \pm 0.01$ \\
$\mathrm{~K}^{+}$ & $2.41 \pm 0.05$ \\
$\mathrm{Cl}^{-}$ & $1.25 \pm 0.04$ \\
\hline
\end{tabular}

the standard method by desiccation at $102-105{ }^{\circ} \mathrm{C}$ for $7 \mathrm{~h} \mathrm{[7]}$. Total protein and non-protein nitrogen (NPN) were determined by the Kjeldahl procedure [8].

Ash was determined by incineration of $10 \mathrm{~mL}$ of sample at $550{ }^{\circ} \mathrm{C}$ for $4 \mathrm{~h}$ [1]. The mineral content $\left(\mathrm{Ca}^{2+}, \mathrm{Mg}^{2+}, \mathrm{K}^{+}, \mathrm{Na}^{+}\right)$of the samples were quantified by atomic absorption spectrometry on a Varian AA 300 equipment (Sunnyvale, USA), according to the method described by Brulé et al. [2]. Chloride content was determined directly on a Corning Model 926 equipment (Humeau, La Chapelle, France).

Lactose content of the samples was determined from mass balance (total solids - ash - protein). The chemical oxygen demand (COD) of the permeate was determined by using a LCK 014 DCO test (Dr. Lange, Düsseldorf, Germany).

Solute retention $(\mathrm{R})$ by the membrane was calculated as follows:

$$
\mathrm{R}(\%)=\frac{\mathrm{C}_{\mathrm{r}}-\mathrm{C}_{\mathrm{n}}}{\mathrm{C}_{\mathrm{n}}} \times 100
$$

where $C_{r}=$ concentration of solute in the retentate and $C_{n}=$ concentration of solute in the nanofiltrate. 


\subsection{Economic analysis}

NF processing cost, including operating (without cleaning) and capital costs, was estimated for each couple $\left(J, \tau_{w}\right)$ on the basis of a NF plant functioning in recirculation mode at constant VRR 2. This plant is supposed to produce a permeate flow rate $\dot{\mathrm{V}}_{\mathrm{P}}\left(\mathrm{m}^{3} \cdot \mathrm{s}^{-1}\right)$ with a total membrane area $\mathrm{A}$ $\left(\mathrm{m}^{2}\right)$, depending on the constant permeate flux value $J$ :

$$
\mathrm{A}=\frac{\dot{\mathrm{V}}_{\mathrm{P}}}{J} \text {. }
$$

The hydraulic setup includes:

- a positive feed pump delivering a flow rate $\mathrm{V}_{\mathrm{F}}=2 \mathrm{~V}_{\mathrm{P}}\left(\mathrm{m}^{3} \cdot \mathrm{s}^{-1}\right)$ under the NF operating pressure TP $(\mathrm{Pa})$ required to keep $J$ constant;

- a recirculating pump on the retentate loop, delivering a flow rate $\mathrm{V}_{\mathrm{R}}\left(\mathrm{m}^{3} \cdot \mathrm{s}^{-1}\right)$ under the pressure drop $\Delta \mathrm{P}(\mathrm{Pa})$ required to keep $\tau_{w}$ constant.

The power $\mathrm{P}_{\mathrm{P}}(\mathrm{W})$ required for this setup is given by:

$$
\mathrm{P}_{\mathrm{P}}=\frac{\dot{\mathrm{V}}_{\mathrm{F}} \cdot \mathrm{TP}}{\xi_{\mathrm{F}}}+\frac{\dot{\mathrm{V}}_{\mathrm{F}} \cdot \Delta \mathrm{P}}{\xi_{\mathrm{R}}}
$$

with $\xi_{\mathrm{F}}=0.5$ and $\xi_{\mathrm{R}}=0.5$, the global efficiencies of the feed pump and the recirculating pump, respectively. The corresponding energy consumption per permeate volume $\mathrm{E}_{\mathrm{P}}\left(\mathrm{J} \cdot \mathrm{m}^{-3}\right)$ is:

$$
\mathrm{E}_{\mathrm{P}}=\frac{\mathrm{P}_{\mathrm{P}}}{\dot{\mathrm{V}}_{\mathrm{P}}} \text {. }
$$

This energy input will induce a rise in temperature of the recirculating retentate, that should be cooled by a heat exchanger to keep temperature constant. The cooling plant energy consumption per permeate volume $\mathrm{E}_{\mathrm{C}}\left(\mathrm{J} \cdot \mathrm{m}^{-3}\right)$ can be estimated from:

$$
\mathrm{E}_{\mathrm{C}}=\mathrm{E}_{\mathrm{P}} \times \frac{\xi_{\mathrm{E}}}{\xi_{\mathrm{C}}}
$$

with $\xi_{\mathrm{E}}=0.9$ and $\xi_{\mathrm{C}}=2$, the pump engine efficiency and the cooling plant global effi- ciency, respectively. The total operating costs $O C\left(\$ \cdot \mathrm{m}^{-3}\right)$ is then:

$$
O C=\left(\frac{\mathrm{E}_{\mathrm{P}}+\mathrm{E}_{\mathrm{C}}}{3600}\right) \times e
$$

where $e$ is the electricity cost $\left(0.05 \$ \cdot \mathrm{kWh}^{-1}\right)$. On the other hand, capital costs $C C\left(\$ \cdot \mathrm{m}^{-3}\right)$ are estimated from the following:

$$
C C=\frac{P C \times C F}{t}
$$

where $P C$ is the plant cost $\left(\$ \cdot \mathrm{m}^{-3} \cdot \mathrm{h}\right), C F$ the capital factor $\left(\mathrm{yr}^{-1}\right)$ and $t$ the total operating time $\left(\mathrm{h} \cdot \mathrm{yr}^{-1}\right) . P C$ is a function of the fixed costs (minimal configuration and automation), the total membrane area A, and the membrane and equipment cost: this lies between 1000 and $560 \$ \cdot \mathrm{m}^{-2}$ for $\mathrm{A}$ in the range 30 to $100 \mathrm{~m}^{2}$, respectively. $C F$ includes depreciation, interest and maintenance, and is equal to $0.4 \mathrm{yr}^{-1}$.

The greater the membrane fouling, the lower the total operating time because of longer periods of membrane cleaning. Arbitrarily considering a $10 \%$ decrease of operating time per increase of 1 of $\mathrm{R}_{\mathrm{f}} / \mathrm{R}_{\mathrm{m}}, t$ was calculated on the basis of a theoretical operating time of $8000 \mathrm{~h} \cdot \mathrm{yr}^{-1}$.

\section{RESULTS}

\subsection{Assessment of fouling}

Figure 1 shows the overall fouling $\left(\mathrm{R}_{\mathrm{f}} / \mathrm{R}_{\mathrm{m}}\right)$ at a FV of $20 \mathrm{~L} \cdot \mathrm{m}^{-2}$ as a function of $J / \tau_{w}$, each point corresponding to one of the 25 experiments. The hydraulic resistances of the clean membrane $\left(\mathrm{R}_{\mathrm{m}}\right)$ were between $9.1 \times 10^{13}$ and $9.8 \times 10^{13} \mathrm{~m}^{-1}$, and did not change to any appreciable extent throughout the experimental study. The reversible fouling $\left(R_{f} / R_{m}\right)$ accounted for $92-98 \%$ of the overall fouling.

The evolution of $\mathrm{R}_{\mathrm{f}} / \mathrm{R}_{\mathrm{m}}$ as a function of $J / \tau_{w}$ could be divided into two parts around a critical $J / \tau_{w}$ value of 6.0 . The first part 
Figure 1. Normalized overall fouling hydraulic resistance $\left(R_{f} / R_{m}\right)$ as a function of the $J / \tau_{w}$, ratio, for the nanofiltration processes of concentrated sweet whey. VRR 2; $18^{\circ} \mathrm{C} ; \mathrm{FV} 20 \mathrm{~L} \cdot \mathrm{m}^{-2}$.

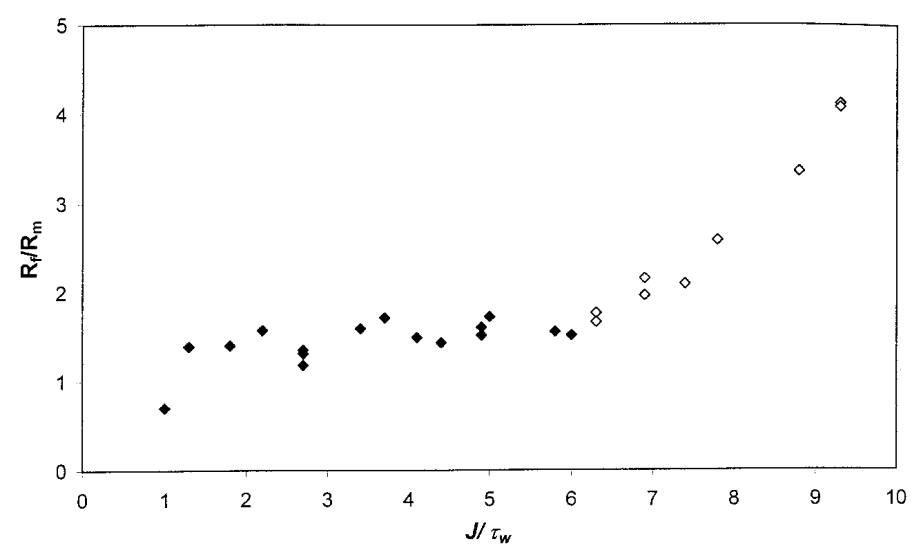

$\left(J / \tau_{w}<6.0\right)$, corresponded to an overall fouling of relatively little importance $\left(\mathrm{R}_{\mathrm{f}} / \mathrm{R}_{\mathrm{m}}\right.$ between 0.7 and 1.5), which slightly increased with $J / \tau_{w}$ (Fig. 1).

Conversely, for higher $J / \tau_{w}$ ratios (> 6.0), there was a very strong dependence between total fouling at the membrane and the ratio $J / \tau_{w}$ : the higher the $J / \tau_{w}$, the higher the $\mathrm{R}_{\mathrm{f}} / \mathrm{R}_{\mathrm{m}}$. Indeed, there was a 2.7 fold increase of $\mathrm{R}_{\mathrm{f}} / \mathrm{R}_{\mathrm{m}}$ from $J / \tau_{w} 6.0$ to $J / \tau_{w} 9.3$ (Fig. 1).

\subsection{Selectivity of the process}

The $J / \tau_{w}$ conditions greatly altered the selectivity of the membrane as shown by large variations in permeate sample composition (Tab. II). Higher losses (20\%) of NPN in the permeate were obtained for lower $J / \tau_{w}$ ratios $\left(J / \tau_{w} 1.0\right)$. Likewise, the higher the $J / \tau_{w}$, the higher the lactose loss in the permeate. Losses of lactose were 0.4 and $1.2 \mathrm{~g} \cdot \mathrm{kg}^{-1}$ for $J / \tau_{w} 1.0$ and 9.3 , respectively, equivalent to 0.4 and $1.1 \%$ of the raw concentrated whey. Consequently, the highest permeate COD values were obtained in the permeate at the highest $J / \tau_{w}$ (Tab. II).

Divalent cations $\left(\mathrm{Ca}^{2+}\right.$ and $\left.\mathrm{Mg}^{2+}\right)$ were almost completely retained whatever the operating conditions used $(\mathrm{R}=97-99 \%$ and $\mathrm{R}=100 \%$ for $\mathrm{Ca}^{2+}$ and $\mathrm{Mg}^{2+}$, respectively) (Fig. 2). However, a higher rejection of monovalent ions was obtained for higher $J / \tau_{w}$ ratios. Rejection of $\mathrm{Na}^{+}$and $\mathrm{K}^{+}$ increased from about $15 \%$, and the rejection of $\mathrm{Cl}^{-}$from about $23 \%$, between $J / \tau_{w}$ 1.0 and 9.3. As a result of the differences found between the monovalent mineral rejection in the experimental study, the ash content of the permeate samples obtained at a FV $20 \mathrm{~L} \cdot \mathrm{m}^{-2}$ was higher when a lower $J / \tau_{w}$ ratio was used $\left(J / \tau_{w} 1.0\right.$ and 3.4 , Tab. I).

\subsection{Economic analysis}

Costs were minimized for $J / \tau_{w}$, ratio in the range 3.0-6.0, at approximately $2 \$ \cdot \mathrm{m}^{-3}$ (Fig. 3). Under $J / \tau_{w} 3$, capital costs were increased because of higher total membrane area A (low $J$ value). Above $J / \tau_{w} 6$, operating and capital costs were increased because of higher operating pressure (high $J$ value) and lower operating time $t$ (higher membrane fouling), respectively.

\section{DISCUSSION}

Fouling occurring during crossflow membrane separation processes of dairy products is a very complex phenomenon, especially in the case of whey, due to the large diversity of dairy components participating in fouling. Generally speaking, the reversible 


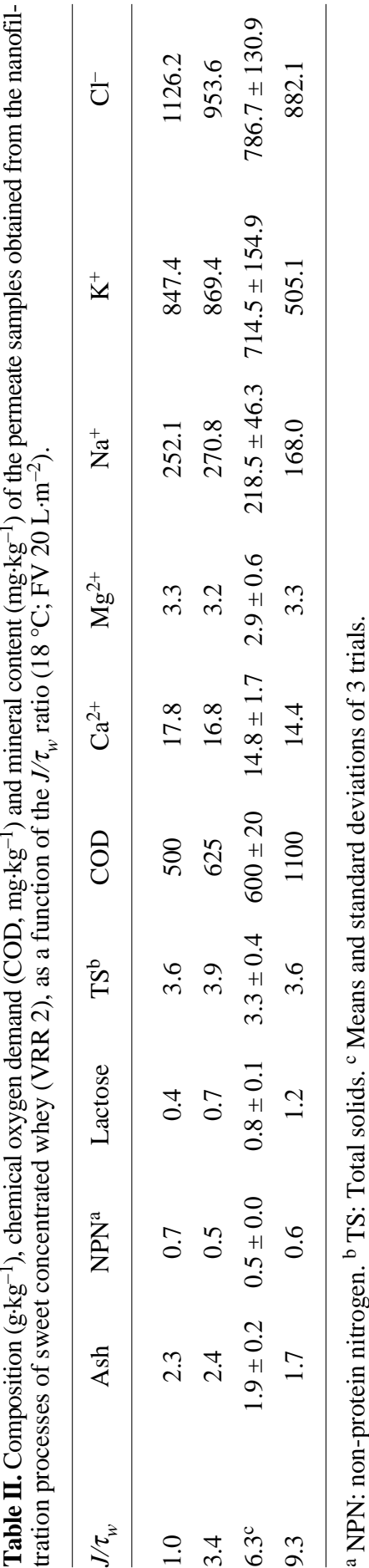

part of fouling based on the concentration polarization $(\mathrm{CP})$ phenomenon is dominant during whey nanofiltration. In the present study, reversible fouling (which involves CP phenomenon) accounted for 92-95\% of the overall fouling. Thus, the control of fouling of sweet whey nanofiltration implied the control of the CP phenomenon. This can be understood as the result of the accumulation of the retained species and of the depletion of the permeating components in the boundary layer adjacent to the membrane, which causes a concentration gradient build up on the latter. Thus, in the present study, from the analysis of nanofiltrate composition and comparing the experimental retentions of whey components, the CP layer was expected to consist mainly of divalents salts, lactose and proteins. Consequences of the $\mathrm{CP}$ build up could be the following. Firstly, the boundary layer characteristics would result in an intrinsic mass transfer coefficient, related to the solute diffusivity within the boundary layer, the boundary layer thickness and compaction. This coefficient would control the alteration of flux and selectivity of the fouled NF membrane. Secondly, the over-concentration of negatively charged whey proteins in the CP layer would increasingly trap small inorganic counter ions around the proteins and simultaneously small inorganic co-ions would be electrically repelled. Thirdly, the over-concentration of lactose would enhance the leakage of lactose into the permeate by diffusion across the NF membrane. And finally, as soon as the calcium phosphate concentration at the membrane surface exceeds saturation, precipitation is liable to occur. This would then cause a far more severe fouling as shown by Kelly et al. [11]. Some authors have even linked the increase of the fouling index, due to the formation of a CP layer, to the increase of precipitation of calcium phosphate at the membrane surface [14].

Methods to reduce the $\mathrm{CP}$ phenomenon by a proper choice of membranes and installation [20], by product pretreatment [5-6] 
Figure 2. Percentage of rejection $\mathrm{R}(\%)$ of mineral species during the nanofiltration process of concentrated whey (VRR 2), at $18{ }^{\circ} \mathrm{C}$ and for different ratios $J / t$ $\left(\mathrm{Ca}^{2+}: 0 ; \mathrm{Mg}^{2+}: \bigcirc ; \mathrm{Na}^{+}\right.$: $\left.\square ; \mathrm{K}^{+}: \mathbf{\square} ; \mathrm{Cl}^{-}: \bullet\right)$.

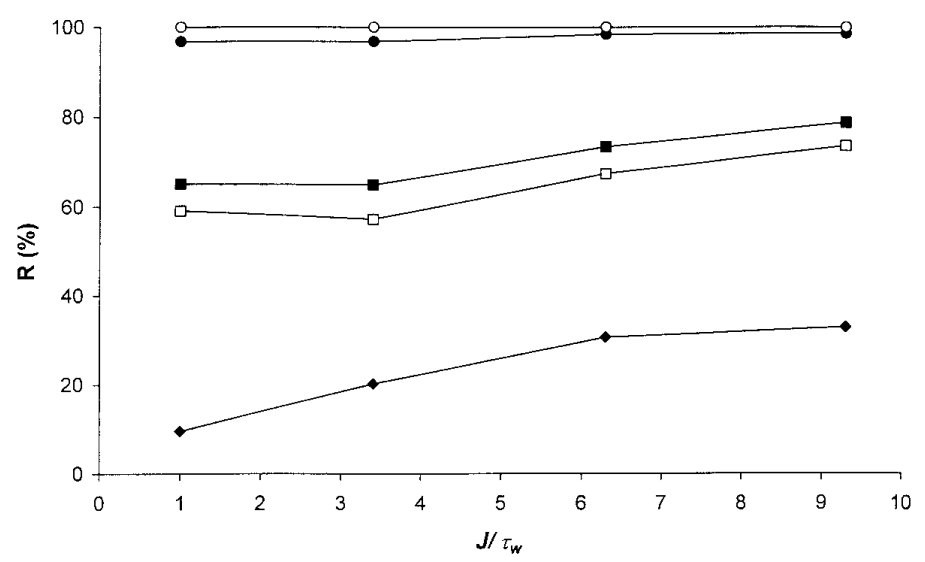

Figure 3. Nanofiltration estimated processing costs $\left(\$ \cdot \mathrm{m}^{-3}\right)$ as a function of the $J / \tau_{w}$ ratio. VRR 2; $18{ }^{\circ} \mathrm{C} ; \mathrm{FV}$ $20 \mathrm{~L} \cdot \mathrm{m}^{-2}$

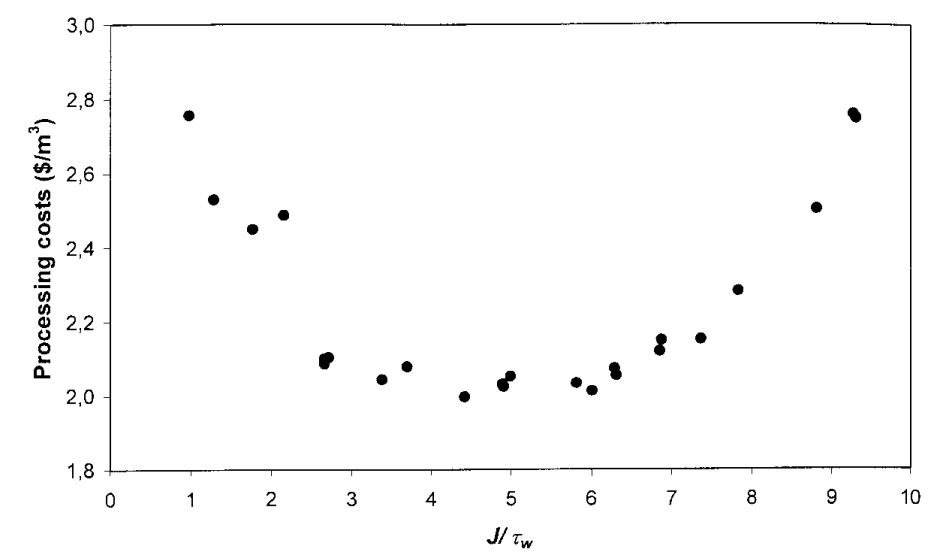

or by the control of the operating variables $[4,13,15]$ are largely described in the literature. Results of the present study highlighted the crucial influence of the ratio between the permeation flux $J$ and the wall shear stress $\tau_{w}$ on the fouling index and on the alteration of process selectivity during the NF of sweet whey. From the knowledge being gathered today in every area of membrane liquid separation, it could be assumed that the two parameters $J$ and $\tau_{w}$ act together in a competing mechanism of convection/erosion. The higher the shear rate, the larger the amount of matter scrapped off the fouling layer. The higher the permeate flux, the larger the amount of matter brought towards the membrane surface and hence the higher the concentration profile in the $\mathrm{CP}$ layer. The competition of both parameters, through the $J / \tau_{w}$ ratio, would thus control the following characteristics of the $\mathrm{CP}$ layer: concentration profile, thickness, compaction and solute diffusivity, and hence, the mass transfer coefficient within the boundary layer.

So, the present results can be understood with regard to the competing mechanism of convection/erosion. As expected from literature, the fouling index was essentially linked to the formation of a $\mathrm{CP}$ layer and this constantly increased with $J / \tau_{w}$. As long as $J / \tau_{w}$ was under a critical value of around 6 , 
the fouling index increased slowly which indicated that mass transport by erosion/ diffusion was greater than mass transport by convection. A more compact, thinner $\mathrm{CP}$ layer was then expected to be formed, which would be probably less able to capture small solutes. Then, as soon as a critical $J / \tau_{w}$ was reached (around 6.0), $\mathrm{R}_{\mathrm{f}} / \mathrm{R}_{\mathrm{m}}$ increased drastically. Some nanofiltration runs even have to be stopped for the highest values of $J / \tau_{w}$. Under these hydrodynamic conditions, the mass transport by convection towards the membrane was far more important than the mass transport by erosion/diffusion, and hence a thicker and looser CP layer settled fast. Because of its specific presumed structure, it was expected to be more liable of capturing the small solutes.

Hence, the selectivity of the NF membrane was greatly altered by $J / \tau_{w}$. With respect to monovalent ions, rejection increased for higher $J / \tau_{w}$, ratios. The interpretation of these results rests on the assumption that the small counter ions of negatively charged whey proteins $\left(\mathrm{Na}^{+}\right.$and $\mathrm{K}^{+}$) were trapped electrically around the proteins, and over concentrated in the $\mathrm{CP}$ layer. On the other hand, the small co-ions of the proteins $\left(\mathrm{Cl}^{-}\right)$were rejected by the negative interface. So, the rejections of small salts increased as the concentration profile of proteins in the vicinity of the membrane increased. The same results were obtained by van der Horst et al. [17] during the NF of model solutions and UF whey permeate.

Opposite results were observed for lactose, since the concentration in the permeate increased when $J / \tau_{w}$ increased. The fouled membrane seemed to be more permeable to lactose. Losses of lactose in the permeate were also reported by Kelly and Kelly [11] using NF organic membranes. It is reasonable to assume that lactose leakage in the permeate was based either on diffusion through the membrane or on convection in the largest pores of the membrane, depending on permeate flux. Whatever the transport mechanism involved, the higher the gradient of lactose concentration across the membrane and hence, the higher the CP, the greater the amount of lactose transferred in the permeate. Moreover, as assumed before, the presumed loose structure of $\mathrm{CP}$ layer under these conditions, would increase the diffusivity of lactose within the boundary layer. So, high values of $J / \tau_{w}$ would have serious repercussions on the polluting power of the nanofiltration process. Indeed, the COD of the nanofiltrate is directly related to the lactose transmission [18]. Losses of organic solids from whey in terms of COD, were similar to those reported by Kelly and Kelly [12] during the NF of acid whey.

To conclude with, the synthesis of these results leads to optimal hydrodynamic operating conditions at VRR 2 and $18{ }^{\circ} \mathrm{C}$ : for a permeate flux equal to $30 \mathrm{~L} \cdot \mathrm{h}^{-1} \cdot \mathrm{m}^{-2}$, the optimal $\tau_{w}$ stands in the range of 6.0-10.0 Pa, corresponding to pressure drops from $0.30 \times 10^{5}$ to $0.50 \times 10^{5} \mathrm{~Pa}$ per element. Under these conditions, longer operating times, lower permeate COD and higher demineralisation can be expected at lower processing costs.

\section{ACKNOWLEDGEMENT}

Dr. J. Rodríguez acknowledges the postdoctoral fellowship from the Spanish Ministry of Education and Science.

\section{REFERENCES}

[1] AOAC, Standard 559 (1945).

[2] Brulé G., Maubois J.-L., Fauquant J., Étude de la teneur en éléments minéraux des produits obtenus lors de l'ultrafiltration du lait sur membrane, Lait 54 (1974) 600-615.

[3] Daufin G., Labbé J.P., Quémerais A., Michel F., Fouling of an inorganic menbrane during ultrafiltration of defatted whey protein concentrates, Neth. Milk Dairy J. 45 (1991) 259-272.

[4] Garem A., Jeantet R., Fouling occurring in nanofiltration of dairy products, in: Fouling and cleaning in pressure driven membrane processes, IDF Special Issue 9504 (1995) 71-79.

[5] Hiddink J., de Boer R., Nooy P.F.C., Reverseosmosis of dairy products, J. Dairy Sci. 63 (1980) 204-214. 
6] Hong S., Elimelech M., Chemical and physical aspects of natural organic matter fouling of nanofiltration membranes, J. Membrane Sci. 132 (1997) 159-181.

[7] IDF, Dry matter and ash, Standard 21, International Dairy Federation, Brussels, Belgium, 1962.

[8] IDF, Détermination de la teneur en azote, Standard 20B, International Dairy Federation, Brussels, Belgium, 1993.

[9] Jeantet R., Nanofiltration de liquides laitiers, Thèse de l'Ecole Nationale Supérieure Agronomique de Rennes, 9518B65, 1995, 139 p.

[10] Jeantet R., Schuck P., Famelart M.H., Maubois J.-L., Intérêt de la nanofiltration dans la production de poudres de lactosérum déminéralisées, Lait 76 (1996) 283-301.

[11] Kelly J., Kelly P., Nanofiltration of whey: quality, environmental and economic aspects, J. Soc. Dairy Technol. 48 (1995) 20-25.

[12] Kelly P.M., Horton B.S., Burling H., Partial demineralisation of whey by nanofiltration, in: New applications of membrane processes, IDF Special Issue 9201 (1992) 130-140.

[13] van Boxtel A.J.B., Fouling control during the operation of membrane filtration units (RO and UF), in: Fouling and cleaning in pressure driven membrane processes, IDF Special Issue 9504 (1995) 93-117.

[14] van Boxtel A.J.B., Otten Z.E.H., van der Linden H.J.L.J., Evaluation of process models for fouling control of reverse osmosis of cheese whey, J. Membrane Sci. 58 (1991) 89-111.

[15] van Boxtel A.J.B., Otten Z.E.H., van der Linden H.J.L.J., Dynamic optimization of a onestage reverse osmosis installation with respect to membrane fouling, J. Membrane Sci. 65 (1992) 277-293.

[16] van der Horst H.C., Fouling of organic membranes during processing of dairy liquids, in: Fouling and cleaning in pressure driven membrane processes, IDF Special Issue 9504 (1995) $36-52$.

[17] van der Horst H.C., Timmer J.M.K., Robbertsen T., Leenders J., Use of nanofiltration for concentration and demineralization in the dairy industry: model for mass transport, J. Membrane Sci. 104 (1995) 205-218.

[18] van der Horst H.C., Timmer J.M.K., Robbertsen T., Leenders J., Nanofiltration for concentration and demineralization of cheese whey: a mass transport model, in: Advances in membrane technology for better dairy products, IDF Bulletin 311 (1996) 9-11.

[19] van Gauwbergen D., Baeyens J., Macroscopic fluid flow conditions in spiral-wound membrane elements, Desalination 110 (1997) 287-299.

[20] Wessels L.P., van der Meer W.G.J., van Paassen W.C., Vos G., Innovative design of nano- and ultrafiltration plants, Desalination 119 (1998) 341-345

\begin{tabular}{|c|c|c|c|}
\hline \multicolumn{4}{|c|}{ List of symbols } \\
\hline A & Total membrane area $\left(\mathrm{m}^{2}\right)$ & $P C$ & Plant cost $\left(\$ \cdot m^{-3} \cdot h\right)$ \\
\hline$C C$ & Capital costs $\left(\$ \cdot \mathrm{m}^{-3}\right)$ & $P_{P}$ & Installation power $(\mathrm{W})$ \\
\hline$C F$ & Capital factor $\left(\mathrm{yr}^{-1}\right)$ & $\mathrm{R}$ & Solute retention $(\%)$ \\
\hline $\mathrm{C}_{\mathrm{n}}$ & Nanofiltrate solute concentration $\left(\mathrm{g} \cdot \mathrm{kg}^{-1}\right)$ & $\mathrm{R}_{\mathrm{f}}$ & Overall fouling hydraulic resistance $\left(\mathrm{m}^{-1}\right)$ \\
\hline COD & Chemical oxygen demand $\left(\mathrm{mg} \cdot \mathrm{kg}^{-1}\right)$ & $\mathrm{R}_{\mathrm{if}}$ & Irreversible fouling hydraulic resistance $\left(\mathrm{m}^{-1}\right)$ \\
\hline $\mathrm{CP}$ & Concentration polarization & $\mathrm{R}_{\mathrm{m}}$ & Clean membrane hydraulic resistance $\left(\mathrm{m}^{-1}\right)$ \\
\hline $\mathrm{C}_{\mathrm{r}}$ & Retentate solute concentration $\left(\mathrm{g} \cdot \mathrm{kg}^{-1}\right)$ & $\mathrm{R}_{\mathrm{m}}$ & Reversible fouling hydraulic resistance $\left(\mathrm{m}^{-1}\right)$ \\
\hline $\mathrm{d}^{\mathrm{T}}$ & Hydraulic diameter of the membrane $(\mathrm{m})$ & $t$ & Total operating time $\left(\mathrm{h} \cdot \mathrm{yr}^{-1}\right)$ \\
\hline$e$ & Electricity cost $\left(0.05 \$ \cdot \mathrm{kWh}^{-1}\right)$ & TP & Transmembrane pressure $(\mathrm{Pa})$ \\
\hline $\mathrm{E}_{\mathrm{C}}$ & Cooling plant energy consumption per per- & VRR & Volume reduction ratio \\
\hline & meate volume $\left(\mathrm{J}^{\mathrm{m}}{ }^{-3}\right)$ & $\dot{\mathrm{V}}_{\mathrm{F}}$ & Positive feed pump flow rate $\left(\mathrm{m}^{3} \cdot \mathrm{s}^{-1}\right)$ \\
\hline $\mathrm{E}_{\mathrm{P}}$ & $\begin{array}{l}\text { Pump energy consumption per permeate vol- } \\
\text { ume }\left(\mathrm{J} \cdot \mathrm{m}^{-3}\right)\end{array}$ & $\dot{\mathrm{V}}_{\mathrm{P}}^{\mathrm{r}}$ & Permeate flow rate $\left(\mathrm{m}^{3} \cdot \mathrm{s}^{-1}\right)$ \\
\hline $\mathrm{FV}$ & Filtered volume $\left(L \cdot \mathrm{m}^{-2}\right)$ & $\dot{\mathrm{V}}_{\mathrm{R}}$ & Recirculating pump flow rate $\left(\mathrm{m}^{3} \cdot \mathrm{s}^{-1}\right)$ \\
\hline$J$ & Permeation flux $\left(\mathrm{m}^{3} \cdot \mathrm{s}^{-1} \cdot \mathrm{m}^{-2}\right)$ & $\xi_{\mathrm{C}}$ & Cooling plant global efficiency \\
\hline & Module length $(\mathrm{m})$ & $\xi_{\mathrm{E}}$ & Pump engine efficiency \\
\hline NPN & Non-protein nitrogen $\left(\mathrm{g} \cdot \mathrm{kg}^{-1}\right)$ & $\xi_{\mathrm{F}}$ & Feed pump efficiency \\
\hline$O C$ & Total operating costs $\left(\$ \cdot \mathrm{m}^{-3}\right)$ & $\xi_{R}^{r}$ & Recirculating pump efficiency \\
\hline$\Delta \mathrm{P}$ & Pressure drop across the membrane $(\mathrm{Pa})$ & $\tau_{w}$ & Wall shear stress $(\mathrm{Pa})$ \\
\hline
\end{tabular}

